удк 658.7

DOI: https://doi.org/10.32851/2708-0366/2021.9.6

Пономаренко I.B.

кандидат економічних наук, доцент, Київський національний університет технологій та дизайну ORCID: https://orcid.org/0000-0003-3532-8332

Козачук А.C. магістр,

Київський національний університет технологій та дизайну ORCID: https://orcid.org/0000-0001-6093-2377

Ponomarenko Ihor, Kozachuk Anastasiia Kyiv National University of Technologies and Design

\title{
ПОБУДОВА КЛІЄНТООРІЄНТОВАНОСТІ ШЛЯХОМ ЗАСТОСУВАННЯ КОНЦЕПЦІї LEAN-MЕНЕДЖМЕНТУ
}

\author{
BUILDING CLIENT ORIENTATION \\ BY APPLYING LEAN MANAGEMENT CONCEPT
}

У статті досліджено актуальність застосування лін-технологій на виробниитві, те, як ия кониепція розвиває процеси всередині підприємства та яким чином впливає на остаточний результат, щуо отримує клієнт. Встановлено зв'язок між прочесами виробництва та відділів, розтачованих у межах офісу, а також показано, як ие пов'язано зі становленням компанії на ринку. Розглянуто кроки та основні інструменти впровадження lеап-менеджменту у різних сферах, а також наведено результати, які були досягнені компаніями, що вже звернулися до методики лін-мислення. Розкрито основні принципи та доиільність їх використання. Наведено характеристику 5S-системи в рамках lеап-менеджменту, щзо дає змогу компаніям запровадити підходи раџіоналізації робочого місия. Встановлено, щзо lеап-кониееція безпосередньо допомагає стати фірмі клієнтоорієнтованою за допомогою оптимізаиії проиесів. Розкрито особливості запровадження підходів lеап-менеджменту украӥнськими компаніями в сучасних умовах.

Ключові слова: lеап-менеджмент, клієнтоорієнтованість, ефективність, оптимізаичія, ощзадливий офіс.

В статье исследована актуальность применения лин-технологий на производстве, то, как эта концепция развивает процессы внутри предприятия и каким образом влияет на окончательный результат, который получает клиент. Установлена связь между проиессами производства и отделов, расположенных в пределах офиса, а такље показано, как это связано со становлением компании на рынке. Рассмотрены шаги и основные инструменты внедрения lеап-менеджмента в разных сферах, а также приведень результаты, которые были достигнуты компаниями, которые уже обратились к методике лин-мылиления. Раскрыты основные приниипы и иелесообразность их использования. Приведена характеристика 5S-системы в рамках lеап-менеджмента, которая позволяет компаниям внедрить подходь раџионализации рабочего места. Установлено, что lеап-концепция непосредственно помогает стать фирме клиентоориентированой с помощьью оптимизации процессов. Раскрыты особенности внедрения подходов lеап-менеджмента украинскими компаниями в современных условиях.

Ключевые слова: lеап-менеджмент, клиентоориентированность, эффективность, оптимизация, бережливый офис.

The article examines the relevance of the use of line technologies in production, how this concept develops processes within the enterprise and how it affects the final result obtained by the client. The connection between the production processes and the departments located within the office is established and it is shown how concept is connected with the formation of the company in the market. The study and application of lean technologies by companies 
is necessary to conduct a proper audit of the company and find new approaches to process optimization. Characteristic features and differences in the introduction of lean-technologies in different types of economic activity are given. The steps and main tools for the implementation of lean management in various fields are considered and the results achieved by companies that have already resorted to the method of lean-thinking are presented. The basic principles and expediency of their use are revealed. Organizations that follow lean have a strong competitive advantage because they respond very quickly and extremely disciplined to market demand rather than trying to predict the future. Lean is needed by the team to focus on learning as quickly as possible, researching consumer needs and deciding how to meet them. Lean management in production can be similarly applied in the office; however, there are some specific points. The characteristics of the 5S-system within the framework of lean-management are given, which allows companies to implement approaches to workplace rationalization. It is established that the lean-concept directly helps the company to become customer-oriented through process optimization. Peculiarities of introduction of lean-management approaches by Ukrainian companies in modern conditions are revealed. It is necessary to adjust the flow of value creation in the work, the sequence of actions to meet customer needs. Lean considers any area of business in terms of process optimization by all employees of the company, so the most effective result is achieved by the synergy of the implementation of line management in production and in the office.

Key words: lean management, customer focus, efficiency, optimization, lean office.

Постановка проблеми. Задоволеність потреб клієнта є головним показником ефективності, що регулярно вимірюється компаніями в процесі вдосконалення відповідних маркетингових стратегій у офлайн- та онлайн-середовищі. Безперервне зростання потреб клієнтів вимагає від гравців ринку постійного вдосконалення та адаптації власної продукції задля забезпечення високого рівня конкурентоспроможності у довгостроковій перспективі. В сучасних умовах важливо максимально приділяти увагу фактору лояльності клієнтів.

Аналіз останніх досліджень і публікацій. Впровадження та доцільність застосування lean-інструментів висвітлені у працях таких учених, як Т. Оно [1], П. Маєрсон [2], Н. Катко [3], Д. Саскін [4], Т. Фабріціо, Д. Тепінга [6].

Формулювання цілей статті. Вивчення принципів lean-менеджменту для підвищення ефективності показників компанії сприяє досягненню цілей, спрощенню та розв'язанню задач. Висока якість продукту або надання послуг може бути забезпечена завдяки завчасно виявленим недолікам та їх усуненню шляхом оптимізації процесів, що одночасно приводить до появи у компанії конкурентних переваг.

Виклад основного матеріалу. Все більше українських компаній звертають свою увагу на lean-менеджмент, що являє собою концепцію ощадливого виробництва, тобто ведення бізнесу, яке орієнтоване на безперервне створення привабливої цінності для споживача та охоплює всі процеси організації і їх постійне вдосконалення шляхом залучення наявного у компанії персоналу та приведення у відповідність до економічних реалій витрат.

Вивчення та застосування компаніями lean-технологій необхідні, щоби провести правильний аудит компанії та знайти нові підходи до оптимізації процесів. Історія запровадження лін-менеджменту почалася з компанії “Тоуоta" - японського автовиробника, що досі утримує звання найбільшої автомобілебудівної компанії у світі за обсягами продажів.

Виробнича система «Тойоти» орієнтована на повне виключення втрат і засновується на таких двох принципах:

- принцип «точно вчасно» (“just-in-time”);

- принцип автономізації (“autonomation”) або автоматизації з використанням інтелекту.

Сутність принципу «точно вчасно» полягає в тому, що під час виробничого процесу необхідні деталі для збору з'являються на виробничій лінії суворо в той момент, коли це потрібно і в суворо необхідній кількості. Як наслідок, компанія, що послі- 
довно впроваджує подібний принцип, може досягти мінімального необхідного рівня складських запасів, знижуючи витрати на зберігання відповідної продукції.

3 точки зору управління виробництвом це $\epsilon$ ідеальним станом. Однак для такої складної продукції, як автомобіль, що містить тисячі деталей, виробничий процес буде складатися з безлічі операцій. Очевидно, що застосування першого принципу до виробничого плану кожного процесу надскладне.

Саме тому «Тойота» віддає перевагу автономізації - станкам, які справляються 3 подібними проблемами самостійно або «автономно» за допомогою простої автоматизації. Відправною точкою такої ідеї послугував самопривідний ткацький станок, винайдений Тойода Сакіті, засновником “Тоуota Motor”. У станок було влаштовано пристрій, що відрізняв нормальне та анормальне протікання виробництва, що перешкоджало появі дефектної продукції.

Автономізація змінює сутність експлуатації станка. Якщо робочий процес добре влаштований, станку не потрібен оператор. Втручання фахівця відбувається лише тоді, коли станок зупиняється через збій. Якщо на виробництві виникає проблема на початку процесу, вона завжди приводить до створення продукції з дефектами пізніше [1]. Аналогічно у сфері послуг емоційний стан співробітника, вподобання, усталені думки прямо впливають на кінцевий результат задоволеності клієнта, що є головним у сервісному обслуговуванні. Компанії не створюють лідерів, адже це роблять споживачі, тому важливо налагодити та оптимізувати зв'язки й процеси всередині фірми.

Цілі впровадження lean у різних сферах перетинаються, але мають деякі відмінності. У виробництві це збільшення продажів, підвищення рівня задоволення клієнтів, скорочення часу на виконання процесів (наприклад, виконання замовлення), підвищення продуктивності та рівня доступності товарів. У сервісі це зниження витрат на виконання послуги, підвищення рівня задоволення клієнта, підвищення продуктивності праці співробітників, зниження витрат, збільшення продажів, зростання відсотка запитів, які обробляються вчасно, скорочення часу на виконання процесу. В торгівлі це збільшення продажів, підвищення рівня задоволення клієнта, скорочення часу на виконання процесів, підвищення продуктивності, підвищення рівня доступності товарів. В ІТ-компаніях це зниження вартості проєкту, зниження часу ttm (“time to market”) продукту, підвищення частоти delivery до клієнта, оптимізація взаємодії між командами розробки, зменшення кількості помилок у додатках, підвищення ефективності роботи відділу $\mathrm{ba} / \mathrm{pm}$, скорочення часу обробки замовлення від клієнта, скорочення втрат під час розроблення продукту [7].

Організації, які слідують lean, мають сильну конкурентну перевагу, тому що вони дуже швидко і надзвичайно дисципліновано реагують на ринковий попит, а не намагаються прогнозувати майбутнє. Lean необхідний команді, щоб зосередитися на навчанні якомога швидше, досліджувати потреби споживачів та вирішити, яким чином їх задовільнити [5]. Lean-менеджмент на виробництві аналогічним чином може застосовуватися в офісі, однак тут $є$ певні специфічні моменти.

Ощадливий офіс - засіб боротьби зі втратами, тому їх класифікація і виявлення $\epsilon$ ключовим. Так, і на виробництві можна окреслити сім таких видів втрат, як брак, запаси, зайва обробка, переміщення, рух, очікування, перевиробництво (зайва робота).

Кроки до ощадливого офісу є такими:

1) впровадження лін-менеджменту в офісі, що $є$ заохоченням у процес усіх співробітників компанії; необхідно спільно обговорювати проблеми фірми та виставляти пріоритетні цілі для покращення роботи;

2) безпосереднє застосування інструментів lean-менеджменту;

3) процес безперервного покращення.

Найпоширеніший інструмент впровадження лін-менеджменту - 5S-система раціоналізації робочого місця. Покрокове її виконання виглядає таким чином: сортуй, самоорганізовуйся, дотримуйся порядку, стандартизуй та зберігай досягнуте [6]. 
Розглянемо кожен пункт системи 5S.

1) SEIRI - сортування, видалення зайвого.

На робочому місці всі предмети розділяються на необхідні та непотрібні. Видалення останніх приводить до покращення культури та безпеки праці. Всі співробітники заохочені в процес сортування й розподілу предметів, які мають бути або негайно вилучені з робочого місця, або перенесені у місця для збереження, або залишені як ті, що необхідні у використанні.

2) SEITON - самоорганізація, дотримання порядку та визначення свого місця для кожної з речей.

Слід навести порядок з необхідними предметами, які розподіляються таким чином, щоб це було зручно та легкодоступно для всіх, хто їх використовує. Важливо також зазначити на них маркування для швидкого пошуку.

3) SEISO - дотримання порядку, систематичне прибирання.

Створюється система в якій більше нічого не забруднюється. Слід впевнитися, що все знаходиться на своїх місцях. Робочі зони мають бути розмежовані та відмічені. Регулярно та часто слід прибирати для того, щоб тоді, коли колективу компанії щось стане необхідним, воно знаходилось на місці і у справному робочому стані.

4) SEIKETSU - стандартизація процесу.

Слід підтримувати порядок та чистоту за допомогою регулярного виконання перших трьох кроків. Найефективніші рішення, знайдені в ході реалізації перших трьох складових частин $5 \mathrm{~S}$, мають бути закріплені письмово, щоб стати наочними й такими, що легко запам'ятовуються. Треба розробити стандарти документів, прийомів роботи, обслуговування обладнання, техніки безпеки з використанням візуального контролю.

5) SHITSUKE - удосконалення порядку та дисципліна.

Для підтримання робочого місця в нормальному стані слід виконувати роботу дисципліновано, згідно зі з встановленими стандартами. Треба усвідомлювати систему $5 \mathrm{~S}$ як загальноприйняту щоденну діяльність та покращувати іiі. Необхідно візуалізувати дії зі вдосконалення, а саме виявляти їх в обладнанні, занотовувати пропозиції щодо їх змін з оптимізації, впроваджувати нові, ще кращі стандарти.

В Україні вже $є$ достатньо компаній, що запровадили у свою систему lean-менеджмент і досягли нових результатів. Так, «Нова пошта» скоротила час оброблення замовлень на 55\%, скоротила помилки відвантажень на 67\%; «Біофарма» збільшила ефективність процесів вдвічі за леофіними препаратами, знизивши брак на 45\%; «МХП» підвищив ефективність роботи обладнання з 83\% до 93\%, збільшив обсяги виробництва на 8,6\% [7].

Приклад вдалого впровадження lean-менеджменту також розглянемо на ринку логістики, а саме бразильського портового терміналу, адже, як уже було зазначено, lean застосовується не лише на виробництві, але й у сфері послуг. Портовий термінал “Ageo”, призначений для зберігання хімікатів та палива, розташовується на острові біля міста Сантос (Бразилія). У 2016 р. він розпочав свою трансформацію. В організації помітили необхідність скорочення часу обслуговування клієнтів, оскільки мета задоволення потреби споживача за максимум дві з половиною години або менше досягалася вкрай рідко. Щоденно надто багато часу припадало на втрати, до яких належали очікування водіїв, затримки під час завантаження продукції у вантажні автомобілі, а також неавтоматизоване управління, що прослідковувалось під час усіх процесів. Як наслідок, це значно впливало на кліснтів, затримки у логістиці були неприйнятними, тому працівники “Ageo” вирішили кардинально змінити робочий процес.

Сьогодні завдяки застосуванню лін-принципів термінал “Ageo” досяг таких кількісних результатів, як скорочення середнього часу обслуговування на $75 \%$; зменшення на 50\% та 33\% часу завантаження та вивантаження відповідно; скорочення понаднормових робіт на 79\%; скорочення часу, необхідного для перевірки на 90\% (зокрема, 
завдяки переходу від записів вручну до записів на планшетах і ПК, що також гарантує оновлення інформації в реальному часі) [8].

Зокрема, були помітні результати, які неможливо зафіксувати кількісно. До них належить етап реєстрації, що став більш адаптованим до обсягу повсякденного попиту, також було скорочено повторюваність процесів. Витрати часу знизилися під час оптимізації процесів, при цьому задоволеність клієнтів значно збільшилась.

Висновки. Lean - це методологія, яка полягає у донесенні максимальної цінності до клієнта через мінімізацію втрат і безперервне покращення. Товар або послуга спершу створюється таким, щоб максимально відповідати запитам клієнта. Бізнес-процеси будуються таким чином, щоб максимально забезпечити задоволеність цієї потреби. Контакти 3 клієнтом організовані таким чином, щоб налаштувати процеси якнайзручніше та комфортніше. Разом це все є факторами для досягнення успіху в побудові клієнтоорієнтованості.

Необхідно налаштувати потік створення цінності у роботі, послідовність дій для задоволеності потреб клієнта. Lean розглядає будь-яку сферу бізнесу з точки зору оптимізації процесів силами усіх робітників компанії, тому найефективніший результат досягається під час синергії впровадження лін-менеджменту на виробництві та в oфici.

Комерційні та маркетингові відділи компаній застосовують методи ощадливого виробництва та лін-мислення для збільшення частки ринку, виведення на ринок нових продуктів, зниження витрат у продажах тощо.

\section{Список використаних джерел:}

1. Toyota Production System. URL: https://global.toyota/en/company/vision-and-philosophy/ production-system (дата звернення: 04.10.2021).

2. Myerson P. Lean Supply Chain and Logistics Management. McGraw-Hill Education, 2012. $288 \mathrm{p}$.

3. Katko N. The Lean CFO: Architect of the Lean Management System. Productivity Press, 2013. $151 \mathrm{p}$.

4. Suskin D. Lean Management: Business Process Optimization: Lean Framework. Independently published, 2021. $110 \mathrm{p}$.

5. Офіційний сайт “Agile Альянсу”. URL: https://www.agilealliance.org/resources/experiencereports/agile-in-the-ukgovernment-an-infiltrators-secrets (дата звернення: 04.10.2021).

6. Fabrizio T., Tapping D. 5S for the Office. Productivity Press, 2006.

7. Lean institute. URL: https://lean.org.ua/lpp (дата звернення: 04.10.2021).

8. Planet Lean. URL: https://planet-lean.com/lean-logistics-ageo (дата звернення: 04.10.2021).

\section{References:}

1. Toyota Production System. URL: https:/global.toyota/en/company/vision-and-philosophy/ production-system (accessed 04 October 2021).

2. Myerson, P. (2012) Lean Supply Chain and Logistics Management. McGraw-Hill Education. Press.

3. Katko, N. (2013). The Lean CFO: Architect of the Lean Management System. Productivity

4. Suskin, D. (2021). Lean Management: Business Process Optimization: Lean Framework. Independently published.

5. Official site of the Agile Alliance. Available at: https:/www.agilealliance.org/resources/experience-reports/agile-in-the-ukgovernment-an-infiltrators-secrets (accessed 04 October 2021).

6. Fabrizio, T., Tapping, D. (2006). 5S for the Office. Productivity Press.

7. Lean institute. Available at: https://lean.org.ua/lpp (accessed 04 October 2021).

8. Planet Lean. Available at: https://planet-lean.com/lean-logistics-ageo (accessed 04 October 2021). 